\title{
RECEPCJA IDEI PRAWNEJ W STANOWIENIU I STOSOWANIU PRAWA
}

\begin{abstract}
Streszczenie. Rozumowanie prawnicze stanowi istotny element tworzenia i stosowania prawa. Dokonywane jest ono na kilku etapach: 1) debata towarzysząca tworzeniu prawa, 2) rozumowanie podmiotu stosującego prawo, 3) dyskurs sądowy i wreszcie 4) doktrynalna ocena rozstrzygnięć judykatury. W stanowieniu i stosowaniu prawa prawodawcy, użytkownicy, sędziowie i glosatorzy dotykają pewnej określonej koncepcji tworzącej normę prawną. Nawiązując do platońskiego zamysłu, można stwierdzić, iż owa koncepcja stanowi pewien byt idealny, który jest odczytywany na poszczególnych etapach. Na przykładzie wybranego przepisu z ustawy o stosunku Państwa do Kościoła katolickiego w RP autor artykułu wskazuje na rolę rozumowań prawniczych w tworzeniu i stosowaniu prawa na wszystkich etapach. Najistotniejsze jest właściwe odczytanie idealnego bytu prawnego oraz klarowne zapisanie go w treści aktów prawnych. Poprawne wykonanie tego zabiegu ułatwi dalsze etapy stosowania prawa.
\end{abstract}

Slowa kluczowe: tworzenie prawa, stosowanie prawa, idea prawna, rozumowanie prawnicze, uzasadnienie normy prawnej.

\section{WPROWADZENIE}

Rozumowanie prawnicze stanowi istotny element tworzenia i stosowania prawa. Dokonywane jest ono na kilku etapach. Cztery z nich, w mojej opinii najistotniejsze, to: 1) debata towarzysząca tworzeniu prawa, 2) rozumowanie podmiotu stosującego prawo, 3) dyskurs sądowy; 4) doktrynalna ocena rozstrzygnięć judykatury. Owe cztery etapy wiążą się ściśle z działaniem prawników oraz innych osób związanych ze stosowaniem prawa.

W obecnych rozważaniach nawiążę do platońskiego mitu jaskini, w którym jedną z idei byłoby konkretne prawo w jego najdoskonalszej postaci (zamysł, koncepcja, założenie itp.). Poszukiwanie podstaw treści prawa jako pewnego bytu nadrzędnego (można by powiedzieć: idealnego) cechowało choćby A. Kaufmanna, który podstawę treści prawa upatrywał w specyficznie rozumianej koncepcji prawa naturalnego (Platon 1997, 220-222; Piechowiak 1992, 34-35). Na potrzeby rozważań przyjmijmy, że prawodawca (lub twórca projektu aktu normatywnego) ma bezpośredni (choć ograniczony zdolnościami percepcyjnymi) dostęp do owego bytu idealnego.

* Uniwersytet Łódzki, Wydział Prawa i Administracji, Katedra Teorii i Filozofii Prawa, malesa.w@gmail.com. 
Dla obrazowości wywodu posłużę się przykładami z polskiej praktyki związanej z jedną z tzw. ustaw majowych, regulujących relacje państwa (wówczas jeszcze PRL) i związków wyznaniowych, w szczególności Kościoła katolickiego, to jest ustawą z dnia 17 maja 1989 r. o stosunku Państwa do Kościoła katolickiego w Polskiej Rzeczypospolitej Ludowej (dalej: u.s.p.k.k.). Ustawa ta projektowana była u schyłku poprzedniego ustroju (lata 80 . XX w.), zapewne jako próba ocieplenia wizerunku ówczesnej władzy poprzez nawiązanie długo oczekiwanych relacji z Kościołem katolickim, który gromadził przeciwników panującego systemu i poczynań rządzących.

Omawiane etapy przedstawię w kolejności odwrotnie chronologicznej. Uzasadnieniem takiej koncepcji niech będzie sposób docierania badacza do prawnego ideału. W większości przypadków bowiem zetknie się on najpierw z publikowanymi glosami, później sięgnie do konkretnego orzeczenia, zbada rozumowanie leżące $\mathrm{u}$ podstaw orzeczenia, $\mathrm{tj}$. pierwotne rozumowanie osoby stosującej prawo, na samym zaś końcu - jeśli jest wystarczająco dociekliwy - spróbuje dotrzeć do pierwotnych materiałów zawierających uzasadnienie dla badanego przepisu, czyli materiału źródłowego najbliższego pierwotnej idei.

\section{DYSKUSJA NAD ROZSTRZYGNIĘCIEM - ETAP DOKTRYNY (IV)}

Przygotowując przed kilkoma laty artykuł dotyczący uprawnień organów kościelnych osób prawnych na gruncie prawa państwowego oraz ograniczeń w prawie reprezentacji jednostek kościelnych, natrafiłem na wiele artykułów naukowych wybitnych polskich znawców prawa wyznaniowego. Wiele z nich stanowiło glosy do orzeczeń.

Zanim jednak przejdziemy do analizy treści wyroków, zastanówmy się nad dialektycznością glos oraz ich znaczeniem w stosowaniu prawa. Stanowią one bowiem - w niniejszym opracowaniu - osobny etap. Glosa to naukowy komentarz do sądowego orzeczenia; jej źródłem jest treść orzeczenia i jego uzasadnienia. Wydający je sąd musi zatem liczyć się z krytyką lub aprobatą prawników-naukowców. Mogą one dotyczyć trzech płaszczyzn:

- głównej idei aktu prawnego stanowiącego podstawę orzeczenia,

- rozumowania podejmowanego przez sąd,

- poprawności proceduralnej.

O ile trzeci przypadek jest nieistotny dla ogólnego tematu, o tyle dwa pozostałe stanowią właściwe rozumowanie prawnicze etapu IV.

W pierwszym przypadku sąd niejako interpretuje zamysł prawodawcy i odczytuje pierwotną ideę przyświecającą przygotowaniu projektu, a następnie przyjęciu przepisu. Nie korzysta jednak z bezpośredniego dostępu do owej idei, do której dostęp miał autor projektu. Bazuje na zasadach wykładni, postrzegając akt w kontekście całego systemu, spójności, zakładając racjonalność prawodawcy 
i wreszcie analizując literalnie semantykę wyrazów, za pomocą których akt ten został spisany (Staśkiewicz 2008, 91-93; Kordela 2006, 43-44).

Na marginesie rozważań należy zauważyć, że samo spisanie aktu odbiera mu idealność. Sam język ogranicza bowiem ideę, jej klarowność i doskonałość w systemie prawnym. Użycie słów do zapisania idei w zgodzie z obowiązującymi normami językowymi oraz prawodawczymi powoduje zatarcie pierwotnego sensu i zamysłu twórców prawa. Wyrazy ograniczają możliwość transmisji danych i pozostawiają dowolność w zakresie interpretacji oraz uzupełniania w przekazie luk, których nie dało się wypełnić słowami. Glosa z pierwszej kategorii dotyczyć będzie zatem sądowego wypełnienia owych luk. Krytyczny glosator będzie przekonany, że idea miała inny cel niż ten, który został stwierdzony przez sąd.

W drugim przypadku, gdy glosator analizuje poprawność rozumowania sądowego, mamy do czynienia ze zgodą co do rozumienia samej idei prawa, zaś komentarz dotyczy jego zastosowania w konkretnym przypadku. Ewentualna krytyka dokonanej subsumcji może odnosić się do przyporządkowania stanu faktycznego pod konkretny przepis prawny. Glosator może tu zarzucać pominięcie istotnych faktów, niespójność rozumowania czy choćby prowadzenie niejednoznacznych implikacji (np. prowadzących do implikacji: $p \Rightarrow q \vee r$, gdzie $q$ lub $r$ zostało niezasadnie pominięte). Przedstawiona sytuacja ma najczęściej miejsce w przypadku sądowych apelacji czy skarg kasacyjnych, jednak występuje również w glosach do orzeczeń, m.in. Sądu Najwyższego czy Naczelnego Sądu Administracyjnego.

W konkretnym przypadku, do którego nawiązuję w niniejszym artykule, glosatorzy podzielili się na dwa fronty: krytyków i zwolenników wydawanych sądowych orzeczeń. W kolejnych glosach dochodziło do polemik pomiędzy specjalistami zajmującymi się prawem wyznaniowym. Na szczególną uwagę zasługują tu glosy M. Pietrzaka oraz B. Rakoczego - profesorów stojących po przeciwnych stronach sporu.

W kontekście słynnego wyroku Sądu Najwyższego z 2000 r. (sygn. IV CKN 88/00) M. Pietrzak zauważył, że SN wymagał znajomości prawa kanonicznego od pracowników banku, jednocześnie nie zwracając uwagi na to, iż to strona kościelna powinna przestrzegać swojego prawa (Pietrzak 2006). Sprawa dotyczyła bowiem umowy kredytu zawartej przez proboszcza katolickiej parafii bez zezwolenia biskupa. Działanie proboszcza bez pisemnej zgody kompetentnego przełożonego, której konieczność uzyskania wynika z przepisów prawa kanonicznego, SN uznał za przekroczenie uprawnień organu, co prowadzi do nieważności dokonanej czynności prawnej. Należy się więc zgodzić z autorem, iż miało miejsce naruszenie równości stron, a proboszcz (którego prawo kanoniczne obowiązuje) działał poza swoimi kompetencjami. W wyniku orzeczenia SN strona, która nie przestrzegała własnych przepisów, odniosła korzyść, pokrzywdzona została natomiast strona przeciwna - działająca $\mathrm{w}$ dobrej wierze i zaufaniu do kontrahenta. 
Drugi z wymienionych glosatorów, B. Rakoczy, stanął po stronie uznania obowiązywalności prawa kanonicznego w polskim systemie prawnym. Swoją glosę podsumowuje on słowami: „Wyrok SN jest istotnym krokiem w kierunku ustalenia normatywnej treści art. 5 konkordatu i art. 2 ustawy wyznaniowej. Dopiero bowiem orzecznictwo sądów określi granice, kiedy zastosowanie znajdzie prawo kanoniczne, a kiedy wyłącznie prawo polskie" (Rakoczy 2003). Autor stoi tu na stanowisku przeciwnym do tego, które prezentuje M. Pietrzak, a jednocześnie aprobuje wyrok SN.

Brak zgody w doktrynie co do słuszności sądowego rozstrzygnięcia sprawy wskazuje, iż uzasadnienie nie było wystarczające. Racjonalne i wyczerpujące uzasadnienie do orzeczenia powinno przekonać wszystkie strony sporu do swojej słuszności. Choć jest to niezwykle rzadkie i trudne, teoretycznie nie jest niemożliwe.

\section{ROZTRZYGNIĘCIE SĄDOWE - ETAP JUDYKATURY (III)}

Jak wspomniałem wyżej, glosowane przez Rakoczego i Pietrzaka orzeczenie SN dotyczyło zawarcia umowy kredytu przez proboszcza katolickiej parafii bez zgody właściwego biskupa diecezjalnego. Zgodnie z prawem kanonicznym ${ }^{1}$ zgoda taka była wymagana. Wątpliwości budzi jednak samo zastosowanie wewnętrznego prawa związku wyznaniowego. W uzasadnieniu wyroku SN wskazuje, iż ustrój osoby prawnej musi być uregulowany w sposób mocny i jawny. Artykuł 35 k.c. odsyła do ustaw lub statutów w zakresie przewidzianym w ustawie. Na mocy art. 38 k.c. osoby prawne działają poprzez swoje organy, lecz sposób ich działania także musi zostać szczegółowo uregulowany. Reguły te dotyczą również kościelnych osób prawnych.

W omawianej sprawie sposób działania organu powinien zostać określony w u.s.p.k.k. ${ }^{2}$ Ustawa jednak nie zawiera takich regulacji. SN utrzymuje, iż ze względu na autonomię Kościoła jedyną kompetentną władzą do uregulowania tej kwestii jest władza kościelna, a przepisami właściwymi - regulacje prawa kanonicznego. Podstawą dla takiego wniosku stał się dla SN art. 2 u.s.p.k.k.

Artykuł ten wyraża jednak przede wszystkim zasadę samorządności Kościoła i jego niezależności od państwa. Dotyczy wewnętrznych spraw Kościoła, a kwestia reprezentacji osób prawnych jest istotna także dla osób trzecich, nie jest zatem sprawą stricte wewnętrzną ${ }^{3}$. Ustawa nie zawiera również odesłania do prawa kanonicznego, zaś art. 3 stanowi, że w sprawach nieuregulowanych stosuje się przepisy prawa powszechnie obowiązującego, do którego nie można zaliczyć prawa kanonicznego (por. Pietrzak 2006).

\footnotetext{
${ }^{1}$ Por. kan. $638 \S 1$ i 3 oraz kan. $1281 \S 1$ KPK.

${ }^{2}$ Stan faktyczny sprawy z 1992 r., a więc przed wejściem w życie Konkordatu.

${ }^{3}$ Por. wyrok Sądu Najwyższego, sygn. IV CK 108/03.
} 
Drugim ważnym orzeczeniem Sądu Najwyższego jest wyrok z dnia 24 marca 2004 r. (sygn. IV CK 108/03)4. W nim SN uznał kompetencje proboszcza do reprezentowania parafii $\mathrm{w}$ stosunkach majątkowych $\mathrm{z}$ osobami trzecimi na zasadach określonych w prawie kanonicznym. Podkreślił jednak, iż prawo kanoniczne może wywoływać skutki w określonej sferze państwowego porządku prawnego tylko wyjątkowo, gdy państwo wyrazi taką wolę w ustawie lub umowie międzynarodowej. Jednocześnie podstawę do zastosowania prawa kanonicznego wywiódł z innych przepisów ${ }^{5}$ - zastosował art. 35 i 38 k.c. w zw. z art. 3 oraz 5-14 u.s.p.k.k. Ustawa przyznaje Kościołowi kompetencje odnośnie do powoływania swoich osób prawnych (z jedynym wymogiem zgłoszenia ich powstania), a także do wskazywania piastunów poszczególnych organów. Z tego SN wnioskuje, iż w obliczu braku przepisów ustawowych dotyczących sposobu reprezentacji kościelnych osób prawnych prawodawca pozostawił to zagadnienie do uregulowania władzy kościelnej6.

Dalej SN podkreślił, że w związku z powyższym prawo kanoniczne powinno być traktowane na równi z ustawami, a nie statutami. Wynikać ma z tego, iż przy ocenie skuteczności działania organu należy brać pod uwagę nie tylko ustawy i prawo kanoniczne, lecz także statuty wydane na jego podstawie. Jest to twierdzenie kontrowersyjne ze względu na obowiązujący na mocy Konstytucji RP zamknięty katalog źródeł prawa.

Przytoczone orzeczenia znów wskazują pewną dialogiczność. Sąd Najwyższy zrewidował własne wcześniejsze uzasadnienie i w kolejnym wyroku - możliwe, iż ze względu na krytykę doktryny - inaczej przeprowadził rozumowanie prawnicze, dążąc do uzasadnienia wydanego wyroku.

Etap IV (związany z doktryną) może pomóc sędziom w ponownym odczytaniu pierwotnej idei prawodawcy, rewizji własnych poglądów, wpływa zatem na kolejne orzeczenia (etap III). Sędziowie, wydając orzeczenia, kierują się bowiem m.in. rozumem i posiadaną wiedzą. Choć nie zawsze mają stopnie i tytuły naukowe, muszą liczyć się z tym, że ich wypowiedzi (formułowane jako uzasadnienia orzeczeń) staną się źródłem dla rozważań naukowców.

\section{STOSOWANIE PRAWA - ETAP UŻYTKOWNIKA (II)}

Na pierwszej „linii ognia” stoi zawsze obywatel, który dane prawo ma zastosować. Nie bez powodu mówi się, że im starsza ustawa, tym lepiej napisana. Współczesne przepisy są co chwilę nowelizowane, pisane językiem niezrozumiałym (prawniczym, urzędowym, technicznym itd.), zawierają liczne odniesienia

\footnotetext{
${ }^{4}$ Orzecznictwo Sadu Najwyższego. Izba Cywilna 4 (2005), poz. 65.

${ }^{5}$ Na niejasność wywodów Sądu Najwyższego zwraca uwagę: Plisiecki 2013, 160.

${ }^{6}$ Nie zgadza się z tym: Januchowski 2007, 64.
} 
do innych aktów prawnych. Trudno się zatem dziwić, że ich odczytanie stanowi nie lada wyzwanie dla laika. Nawet osoby mające pewne obycie w tekstach prawnych, np. urzędnicy, obawiają się samodzielnie podejmować decyzje co do sposobu zastosowania przepisu w konkretnej sytuacji, żądają opinii radców i zatwierdzenia przez przełożonych.

Sytuacja taka jest skutkiem braku zrozumienia pierwotnej idei prawnej oraz obawy przed jej osądem, który może nastąpić w etapie III. Nie można się dziwić zatem, że wielu urzędników wykazuje bierność w stosowaniu prawa.

Rozumowania prawnicze na tym etapie ograniczają się głównie do konsultacji ze specjalistami, analizą dotychczasowych orzeczeń i wypowiedzi doktryny, przytaczanych w uzasadnieniach administracyjnych. Tymczasem sytuacja powinna kształtować się inaczej: pierwotna idea powinna być na tyle czytelna, że każdy stosujący prawo w etapie II powinien wyraźnie rozumieć zamysł prawodawcy i wiedzieć, w jaki sposób prawo stosować. Obecnie jest jednak inaczej. Na ścianie platońskiej jaskini widać pewien kształt. Mało kto chce się podjąć opisania go i interpretacji. Ci, którzy w jakiś sposób zostają do tego „zmuszeni”, biorą na siebie całą odpowiedzialność za powodzenie lub niepowodzenie owej interpretacji. Łatwiej jest bowiem w etapie III lub IV skrytykować opinię wydaną w etapie II, niż samodzielnie przedstawić jakieś stanowisko.

Ta kuriozalna sytuacja ma miejsce wielokrotnie, gdy pojawiają się nowe przepisy. Stosujący je nie są pewni, w jaki sposób należy je interpretować i czekają na orzeczenia oraz wypowiedzi doktryny. A prawo jest przecież tworzone w pierwszym rzędzie dla stosujących je w etapie II. Jeżeli jednak nie jest ono zapisane w formie klarownej i dostęp do idealnego zamysłu jest utrudniony, konieczność zastosowania prawa budzi niechęć.

W kontekście u.s.p.k.k. oraz przytoczonego wyżej orzeczenia (IV CKN 88/00) i glos należy zwrócić uwagę na dwie strony: proboszcza parafii i pracownika banku. Zakładam, że obaj racjonalnie zinterpretowali przepisy dotyczące kredytu. Stali się jednak pierwszymi, których działania zostały tak szeroko omówione i dały pole do analiz dla prawników.

W całej sytuacji zabrakło jasno określonych kompetencji organów kościelnych osób prawnych. Już z perspektywy etapu IV pojawiły się głosy nawiązujące do postulatu stworzenia odpowiedniego rejestru. Należy bowiem zapewnić dostęp do informacji, kto i w jakim zakresie może reprezentować daną jednostkę kościelną. Postulowaną formą rozwiązania niewątpliwego problemu rodzącego się na styku dwóch porządków prawnych jest stworzenie rejestru wyznaniowych osób prawnych, obejmującego informacje o wszystkich działających w Polsce konfesyjnych osobach prawnych, w szczególności parafiach, zborach, diecezjach, stowarzyszeniach itd. Rozwiązanie takie wypracowali i postulowali m.in. M. Pietrzak i A. Januchowski (por. Pietrzak 2006, 31; Januchowski 2007, 56-57; Januchowski 2008, 234-235; Malesa, Wawrzaszek 2014, 275-309). Do tego tematu powrócę jeszcze w kolejnych akapitach. 


\section{TWORZENIE PRAWA - ETAP PRAWODAWCY (I)}

Proces tworzenia prawa rozpoczyna się długo przed oficjalnym rozpoczęciem procesu legislacyjnego. Grupa osób zaangażowanych w daną tematykę kreśli założenia, projekt aktu oraz ocenę skutków regulacji. Im więcej konsultacji, uzgodnień i dyskusji, tym większa szansa, że nowe prawo będzie odpowiadać pierwotnej idei i zaspokoi potrzeby jak największej grupy osób.

Przyjmijmy, według platońskiej koncepcji, że w pierwszym etapie rozumowania „odczytywany” i „kodowany” jest pewien idealny zamysł prawny. Odczytywany - bo twórcy prawa, kreśląc projekt konkretnej ustawy, bazują na swoich przekonaniach, wynikach dialogu społecznego, obietnicach wyborczych oraz innych przesłankach skłaniających ich do ustalenia prawa w konkretnym kształcie. Z kolei kodowanie ma na celu „ubranie w słowa” owej idealnej myśli, która odtąd zostanie wyrażona językiem prawniczym. Etap kodowania ma więc szczególne znaczenie - wymaga on poprawnego rozumienia idei oraz, co chyba jeszcze trudniejsze, opisania go w taki sposób, aby był intersubiektywnie komunikowalny, spójny horyzontalnie, wertykalnie i wewnętrznie (por. Staśkiewicz 2008, 114), a także przedstawiony w sposób na tyle prosty i konkretny, aby jego dekodowanie nie sprawiało trudności osobom stosującym to prawo.

$\mathrm{W}$ omawianym przykładzie związanym z tworzeniem u.s.p.k.k. treść tej ustawy była efektem wieloletniej wspólnej pracy przedstawicieli rządu PRL i Episkopatu Polski, która rozpoczęła się na początku lat 80. ubiegłego stulecia. Nawiązał się wówczas oficjalny dialog na linii państwo - Kościół.

W roku 1981 rozpoczęły się prace zespołu redakcyjnego, składającego się z przedstawicieli rządu i Kościoła. Ich zadaniem było stworzenie projektu ustawy, która opisywałaby cele państwa i Kościoła, którymi kierują się przy normowaniu wzajemnych stosunków. Prace te zostały przerwane w 1983 r., gdyż przygotowany projekt nie został przyjęty jednogłośnie i z tego powodu nie wszedł na drogę legislacyjną.

We wrześniu 1987 r. Komisja Wspólna postanowiła o powołaniu 10-osobowego drugiego zespołu redakcyjnego, w skład którego weszli przedstawiciele rządu i Kościoła. Ogółem w pracach uczestniczyło 37 osób. Zespół miał za zadanie przygotować dwa dokumenty: regulującą sprawy należące do Stolicy Apostolskiej konwencję między Polską Rzecząpospolitą Ludową a Stolicą Apostolską oraz ustawy o stosunku państwa do Kościoła katolickiego, która miała regulować wewnątrzkrajową sytuację Kościoła. Konwencja nie została nigdy przyjęta pod tą nazwą. Stanowiła jednak pewien wzór do późniejszej redakcji Konkordatu z 1993 r. Natomiast projekt ustawy opracowany przez komisję został przyjęty w tajnym głosowaniu przez Konferencję Episkopatu Polski (7-9 marca 1989 r.) i zaakceptowany przez Biuro Polityczne KC PZPR (14 marca 1989 r.) ${ }^{7}$. Tak przygotowany projekt złożono w Sejmie.

${ }^{7}$ Por. Archiwum Akt Nowych w Warszawie (dalej: AAN), Urząd ds. Wyznań w Warszawie, 2/1587/0, sygn. 117/7, k. 280-282. 
W projekcie z 1987 r. znalazł się postulat stworzenia publicznego wykazu wyznaniowych osób prawnych, prowadzonego „do celów dowodowych i informacyjnych"s. Niestety, w ostatecznie zatwierdzonym projekcie ustawy publiczny wykaz zamieniono na powiadomienia, które otrzymują właściwe organy rządowe. Został on usunięty z projektu w 1988 r. na podstawie postulatu strony kościelnej ${ }^{9}$. Utrudnia to dostęp osób trzecich do danych o kościelnych osobach prawnych, ich organach i kompetencjach poszczególnych organów oraz do uzyskiwania zaświadczeń z dokumentów posiadanych przez odpowiednie organy rządowe.

W tym miejscu możemy dość do hipotezy, że niewłaściwa była decyzja Komisji Wspólnej z roku 1988 r. o usunięciu z projektu ustawy artykułu mówiącego o stworzeniu publicznego rejestru kościelnych osób prawnych. Jak się okazuje, powoduje to problemy w stosowaniu prawa (etap II), w orzekaniu na jego podstawie (etap III i zmiana uzasadnień sądu w kolejnych orzeczeniach), a także w dyskusji doktryny (etap IV). Nie możemy z całą pewnością stwierdzić, że dzięki pozostawieniu przepisów z pierwotnego projektu uniknęlibyśmy trudności. Można jednak przypuszczać, że zasadniczy problem dotyczący określenia kompetencji proboszcza prawdopodobnie by nie wystąpił.

\section{PODSUMOWANIE}

Jeżeli przyjąć platońską koncepcję idealizmu, prawo istnieje poza nami. Jego kodyfikacja, stosowanie, ocena stosowania i ocena przeprowadzonej oceny krystalizują kształt idei. W takiej interpretacyjnej funkcji stają zarówno sądy (etap III), jak i przedstawiciele doktryny (etap IV). Stają się oni istotną częścią etapu II, w którym pierwszorzędny użytkownik prawa musi je odpowiednio zastosować.

Rozumność rozumowań prawniczych we wszystkich przedstawionych aktach stanowi niezwykle ważny element tworzenia, stosowania, sądzenia i komentowania prawa. Im bardziej rozumne (w znaczeniu: uzasadnialne oraz racjonalnie akceptowalne w jak najwyższym stopniu dla jak największej liczby osób), tym lepiej dla prawa. Prawo bowiem powinno być na tyle klarowne, aby jego stosowanie nie nastręczało trudności, a sądy nie musiały wypełniać jego luk swoimi utartymi liniami orzeczniczymi. W moim odczuciu proces tworzenia prawa (etap I) lub jego dekodowania z idei (wyrażonej wolą narodu, potrzebą społeczną lub innym ratio legis) jest najistotniejszy w całości procesu rozumowań prawniczych. Gdyby był przeprowadzany poprawnie, dalsze rozumowania byłyby proste, a często nawet zbędne.

\footnotetext{
${ }^{8}$ AAN, Urząd ds. Wyznań w Warszawie, 2/1587/0, sygn. 117/1, k. 32, 61-66.

${ }^{9}$ Por. AAN, Urząd ds. Wyznań w Warszawie, 2/1587/0, sygn. 117/3, k. 58.
} 


\title{
BIBLIOGRAFIA
}

Januchowski, Arkadiusz. 2007. „Skuteczność prawa kanonicznego w zakresie reprezentacji osób prawnych Kościoła katolickiego". Rejent 197: 49-76.

Januchowski, Arkadiusz. 2008. „Wybrane zagadnienia związane z reprezentacją parafii przez proboszcza na gruncie prawa kanonicznego i polskiego". Studia z Prawa Wyznaniowego 11: 211-236.

Kordela, Marzena. 2006. „Zasady prawa jako normatywna postać wartości”. Ruch Prawniczy, Ekonomiczny i Socjologiczny 68: 39-54.

Malesa, Wojciech, Aneta Wawrzaszek. 2014. „Rejestr wyznaniowych osób prawnych”. Studia z Prawa Wyznaniowego 17: 275-309.

Piechowiak, Marek. 1992. W poszukiwaniu ontologicznych podstaw prawa. Arthura Kaufmanna teoria sprawiedliwości. Warszawa-Poznań: Instytut Nauk Prawnych PAN.

Pietrzak, Michał. 2006. „Prawo kanoniczne w polskim systemie prawnym”. Państwo i Prawo 8: 24-30.

Platon. 1997. Państwo. W Państwo, Prawa. Przeł. Władysław Witwicki. T. 1. Kęty: Antyk.

Plisiecki, Marek. 2013. Wyznaniowa osoba prawna w prawie polskim. Warszawa: Wydawnictwo Naukowe Semper.

Rakoczy, Bartosz. 2003. „Glosa do wyroku SN z dnia 27 lipca 2000 r., IV CKN 88/00”. Orzecznictwo Sąów Polskich 9 (115): 491-495.

Staśkiewicz, Wiesław. 2008. „Rozumowania prawnicze w procesie legislacyjnym”. W Rozumność rozumowań prawniczych. Materiały z konferencji Zakładu Praw Człowieka Wydziału Prawa i Administracji Uniwersytetu Warszawskiego, która odbyła się 23 stycznia 2008 roku. Red. Mirosław Wyrzykowski. 89-120. Warszawa: Uniwersytet Warszawski.

\section{Wojciech Malesa}

\section{RECEPTION OF THE LEGAL IDEA IN THE CREATION AND APPLICATION OF LAW}

\begin{abstract}
Legal reasoning is an important element of drafting and applying law. It is done at several stages: 1) a debate during the legislative process; 2) reasoning of the entity applying the law; 3) a judicial discourse and 4) an academic assessment of judicial decisions. In drafting and applying law, the legislators, law users, judges and glossators touch upon a certain norm-creating concept. Following the Platonian concept, we can conclude that the concept is a certain idea which may be interpreted in several stages. With the example of a selected provision from the Act on the Relationship between the State and the Catholic Church in the Republic of Poland, the author of the paper indicates the role of legal reasoning in drafting and applying law at every stage. The most important thing is to interpret the ideal norm in a correct way and clearly draft it as a legal act. Correct performance of this procedure will facilitate further stages of applying the law.
\end{abstract}

Keywords: drafting law, applying law, legal idea, legal reasoning, justification of a legal norm. 